\title{
Developing Trigonometry Mathematic Learning Based On Multiple Intelligence Theory
}

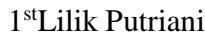 \\ Mathematics Department \\ Universitas Negeri Padang \\ Padang, Indonesia \\ lilikputriani1993@gmail.com
}

\author{
$2^{\text {nd Irwan }}$ \\ Mathematics Department \\ Universitas Negeri Padang \\ Padang, Indonesia \\ irwan@fmipa.unp.ac.id
}

\author{
$3^{\text {rd Dony Permana }}$ \\ Mathematics Department \\ Universitas Negeri Padang \\ Padang, Indonesia \\ donypermana@fmipa.unp.ac.id
}

\begin{abstract}
The aims of this research is to produce trigonometry mathematic learning based on multiple intelligence theory that validity, practically, and effectiveness. The learning that includes base on lesson plan (RPP) and learner's worksheet (LKPD). This development model used in the research is the Plomp's model (preliminary research, prototyping phase, and assessment phase). The research's subject was 23 students at grade X SMAN 05 Mukomuko, Bengkulu. The instrument used in this research was validation sheet, teacher and student's questionnaire and test of mathematic learning result. The product of learning said to be valid if the result learning were valid of content and construct. Practically seen from using the product. Effectiveness seen from the learner's presentation complete on the test least $70 \%$. Expert validation result show that validation assessment. Practically reached category based on teacher and the student's questionnaire. The effective said to be effective based on the mathematic learning. The student's presentation was complete of the test was $73 \%$.
\end{abstract}

Keywords-Multiple Intelligence Theory, Learning Devices, Mathematic Learning's Result, Plomp's Model.

\section{INTRODUCTION}

The need to improve learners' skills according to the 2013 curriculum is very important, whereas in the 2013 curriculum, three aspects become the Qualifications Standards for Graduates, such as Attitude, Knowledge and Skills. skills. One of the potentials of learners and the effect on the skill to be attained is multiple intelligence. Multiple intelligence is an internal factor that already exists in the learner and influences the learning process of the learner. Gardner [1] mentions the importance of recognizing and developing all varied human intelligences and combinations of intelligences. The plural intelligence was put forward by Howard Gardner in the book "Frame of Mind" which was later revised with "Intelligence Reframed". Gardner [1] defines intelligence as the ability to solve problems or create a product. Teachers need to create interactive, inspiring, fun and challenging learning. Multiple intelligence is the range of skills and talents that learners have to solve learning problems [2]. There are nine types of intelligence proposed by Gardner [1]: linguistic, musical, mathematical-logical, visual-spatial, bodily-kinesthetic, intrapersonal, interpersonal, naturalistic and existentialist.

The splendors possessed by the learners are very diverse. With the diversity of intelligence, learners should help teachers to reach learners in an optimal way. Widjajanti [3] mentions that learners' intelligence helps a teacher to develop learning strategies and develop learning tools to facilitate the multiple intelligences held by learners.

The theory of multiple intelligences also considers that humans basically have the capacity to empower these intelligences to the limit. The development of these abilities depends on the learning environment of the learner. Educators need to create a supportive learning environment by applying a learning strategy to make learning more interesting and meaningful. This statement is in agreement with permendikbud [4] that the learning strategy is the systematic steps used by educators to create a learning environment in order to achieve competence.

Learning strategy based on the theory of multiple intelligences on mathematics learning can be applied diverse. Thus, the ninth intelligence that existed among learners can be empowered with the maximum. Learners become more active in the learning process. In addition, learners are able to relate the subject with everyday life or other sciences. Not only the knowledge and mathematical skills possessed by the learners, but also a good attitude. Ula [5] states that every human has not only a kind of intelligence, but is diversified. This is what causes the value of multiple intelligences in the three domains, namely the cognitive, affective and psychomotor domains.

In the 2013 curriculum, the affective aspect (attitude) includes two basic skills, namely KI-1 (spiritual attitude) and KI-2 (social attitude). Social attitudes that learners can achieve in multiple learning-based intelligence confidence, curiosity and criticism. Self-confidence is an attitude of confidence in self-ability, optimistic, courageous express expression, and not easily influenced by others to do things correctly, correctly and effectively against the fulfillment of each desire and hope. This statement is consistent with the opinions of the experts $[6,7,8,9]$. A critical attitude is the attitude of a person who expresses an opinion on information coming from someone else and who objectively considers things [10]. Zuss [11] curiosity is important as a driver to help create new relationships between ideas, perceptions, concepts and representations.

Learners can know any intelligence that is distinguished in him by trust. This is an important step in the use of the theory of multiple intelligences. According to Armstrong [12] an important step in the use of the theory of multiple intelligences is to determine the nature and quality of his intelligence and to look for a way to empower intelligence. 
Thus, learners need a critical attitude and curiosity to empower multiple intelligences.

Multiple intelligences has advantages in learning mathematics, which learners can explore and learn in their own way through the dominant intelligence possessed by learners. Thus, learners can understand mathematical materials. This is in line with Ula's view [5] that "learners will readily grasp the material that the teacher conveys, if the material is provided using the prominent intelligence of the learners."

Many researchers are researching multiple intelligences in mathematics learning. The researcher not only sees the influence of multiple intelligences in the learning of mathematics, for example $[13,14,15,16]$, but also develops a convincing, practical and effective multi-arithmetic mathematical learning tool in learning mathematics, for example $[17,18,19]$. In general, the results showed that multiple intelligence helps learners improve the learning outcomes of learners.

Based on the results of observation and interviews of teachers of mathematics class X SMAN 05 Mukomuko, learning has implemented the 2013 curriculum, but teachers have not empowered the intelligence possessed by learners. In addition, there is still no learning tool that supports learning-based theory of multiple intelligences.

Development of learning tools (RPP and LKPD) trigonometry based on the theory of multiple intelligences to facilitate teachers to implement learning and facilitate the multiple intelligence of learners. Therefore, this study aims to produce trigonometric learning devices based on the theory of multiple intelligences that are valid, practical, and effective based on Nieveen criteria [20].

RPP is a guideline of steps that will be undertaken by the teacher in the learning activities arranged in an activity scenario [21]. The components and principles of RPP development in this study refers to Permendikbud No. 65 Year 2013 on Process Standards. LKPD is a learner's guide used to conduct investigation or troubleshooting activities [21]. In Permendikbud No. 71 of 2013 which regulates textbooks and teacher manuals for elementary and secondary education teaching materials are considered good and worthy of use if they meet the eligibility criteria of content, language, presentation, and graphics.

\section{METHODS}

The research conducted in this research is development research. Borg and Gall [22] say that development research is a research method used to develop or validate products used in education and learning. The research model used in this research is the development model of Plomp. Plomp [23] proposes a development model in three phases, namely the preliminary research phase, the prototype development or prototyping phase and the evaluation phase. In the preliminary research phase there are several activities that collect data, analyze and identify problems that arise in learning as a basis for determining the alternative solutions and product specifications needed, study the material coverage needed to achieve the indicators. of competence. The analysis of this phase includes needs analysis, program analysis, concept analysis, learner analysis.
In prototyping phase, the realization of the prototype is carried out in formative evaluation. The prototyping phase includes prototype 1 , self-assessment and expertise. Selfassessment consists of evaluating the RPP and the LKPD that were designed with the help of colleagues [24]. After repaired, considered good and as expected, then conducted the evaluation phase to the validity of the content by experts or experts (expert reviews). In expert review validated by 5 experts who referring as a validator consists of 3 experts in mathematical education, an expert in educational technology and an expert in Indonesian language.

Prototype 2, which is the result of a one-to-one evaluation. In the individual assessment, three students in class $\mathrm{X}$ have different learning abilities (high, medium and low). Prototype 3, small group assessment. A small group evaluation will be conducted in class X, consisting of 6 people with different learning abilities (high, medium and low) and prototype 4, which is the result of a formative evaluation. During the evaluation phase, field trials were conducted in class $\mathrm{X}$ SMAN 05 Mukomuko to see practicability and effectiveness. The research data was collected using a validation sheet, a teacher response questionnaire and the student response questionnaire, as well as the results of the learners' learning outcomes test.

\section{RESULTS AND DISCUSSION}

The result of the early product development as trigonometric learning based on the multiple intelligences theory using the Plomp model is described as follows. According to the preliminary analysis, students' mathematics learning outcomes are still low. This is seen from the value of the learners' daily test. Based on the results of the observation and interviews with the class $\mathrm{X}$ mathematics teacher at SMAN 05, Mukomuko also obtained information that the teacher did not empower the multiple intelligences possessed by the learners. Moreover, there is no learning tool (RPP and LKPD) that supports the theory based on learning multiple intelligences.

To find out the multiple intelligence of the learners, the researchers conducted a multiple intelligence test in class X IPA 1 SMAN 05 Mukomuko. The test contains statements containing nine compound intelligences, namely linguistic, musical, logical-mathematical, visual-spatial, bodilykinesthetic, intrapersonal, interpersonal, naturalist, and existentialist intelligence. These statements were modified from statements compiled by McKenzie [25]. The results of the learners' multiple intelligence tests are shown in Figure 1 below:

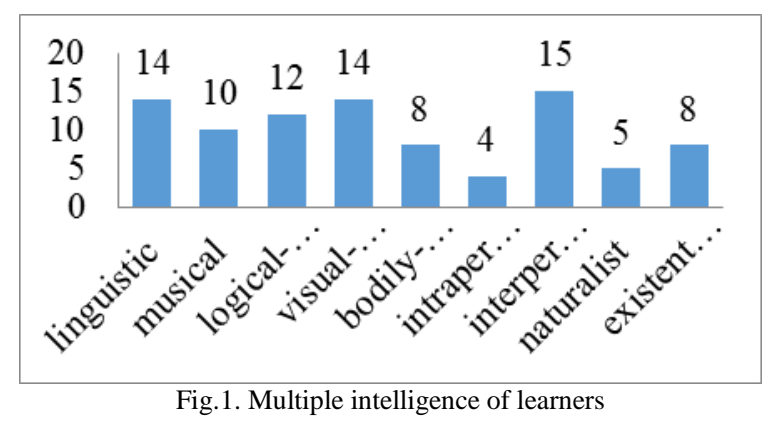

Based on the results of several intelligence tests in Figure 1 , there are some dominant intelligences of IPA SMAN 05 
Mukomuko class X students, namely interpersonal, logicalmathematical, linguistic and visual-spatial intelligence.

In this study, trigonometric learning devices developed more dominantly using the four intelligences. In the learning tools developed (RPP and LKPD), there are learning activities that facilitate linguistic intelligence, interpersonal intelligence, logico-mathematical and visual-spatial learners. The linguistic intelligence of learners is facilitated by group presentations, readings or conclusions; The intelligence interpersonal learning is facilitated by group discussions; the logical-mathematical intelligence of learners is facilitated by mathematical problems; and the visual-spatial intelligence of learners is facilitated by the presentation of materials using power points and illustrated drawings. Therefore, at each meeting, there will be a group discussion and an illustration of the images related to learning mathematics. However, the other five composed intelligences, namely intrapersonal, existentialist, musical, naturalistic and kinesthetic intelligence are further facilitated in the developed learning device. Thus, the mathematics learning device developed further facilitates nine of the multiple intelligences of the learners, although the proportions are not the same.

Trigonometric devices based on the theory of multiple intelligences are validated by three experts in mathematical education, an expert in education in Indonesian language and a specialist in technological education. The results show that RPP and LKPD meet valid criteria [20], with valid RPP and LKPD features in content and construction that include didactic, content, language and presentation aspects. Trigonometric devices based on the theory of multiple intelligences have the potential to facilitate the intelligence possessed by learners so that participants are able to understand the material through the intelligence that it has. Examples of RPP and LKPD of multiple intelligences validated by experts.

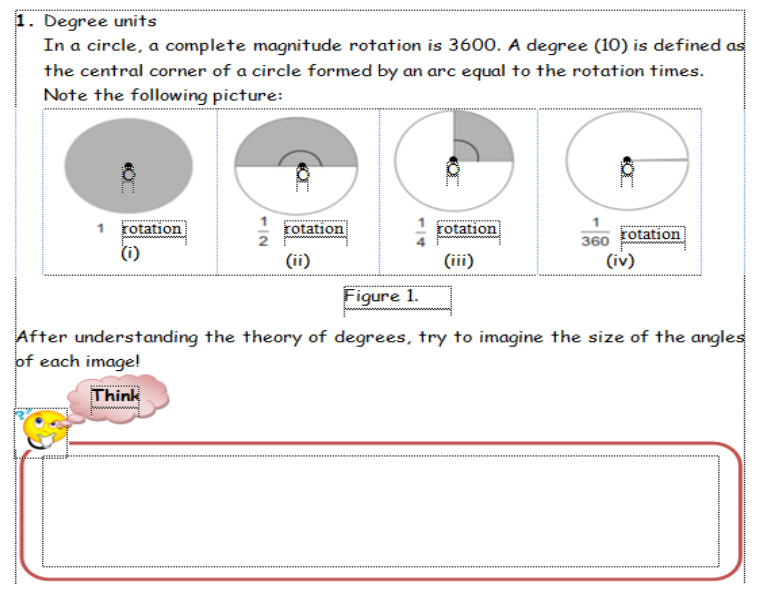

Figure 2. Examples of visual and logical mathematical activities in LKPD

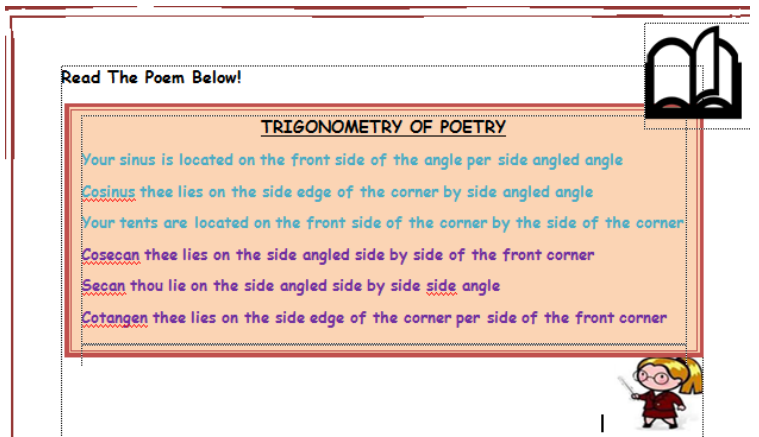

Figure 3. Example of language activity on LKPD

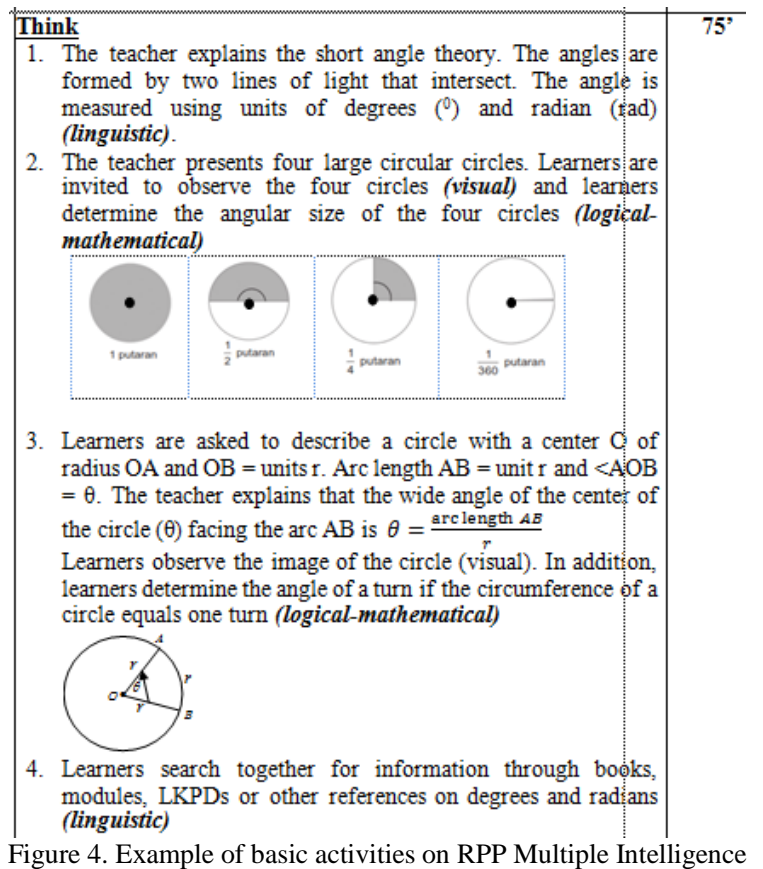

Trigonometric devices based on the theory of multiple intelligences also meet the criteria of practicality [20], in which the RPP and LKPD are easy to use by teachers and learners and also describe the actual learning process.

The practice based on the results of the student questionnaires is presented in the table.

TABLE I. RESULTS OF THE ANALYSIS OF THE DATA OF THE PRACTICAL QUESTIONNAIRE BY THE LEARNERS

\begin{tabular}{|c|c|c|}
\hline $\begin{array}{c}\text { Evaluated } \\
\text { aspects }\end{array}$ & $\begin{array}{c}\text { Average value of } \\
\text { practicality (\%) }\end{array}$ & Category \\
\hline Presentation & 81,66 & Very Practical \\
\hline Use & 84,52 & Very Practical \\
\hline Readability & 85,41 & Very Practical \\
\hline Time & 79,16 & Practical \\
\hline Practical Value & 82,68 & Very practical \\
\hline
\end{tabular}

On the basis of this table, we know that the average percentage of practical questionnaires learner is in a very practical category.

The results of the practical evaluation by teachers after the use of trigonometric devices based on the theory of multiple intelligences are presented in Table 2. 
TABLE II. RESULTS OF THE DATA ANALYSIS OF THE PRACTICAL QUESTIONNAIRE BY MASTER.

\begin{tabular}{|c|c|c|}
\hline $\begin{array}{c}\text { Evaluated } \\
\text { aspects }\end{array}$ & $\begin{array}{c}\text { Average value of } \\
\text { practicality }(\%)\end{array}$ & Category \\
\hline Attraction & 87,50 & Very Practical \\
\hline Process of se & 100 & Very Practical \\
\hline Ease of use & 100 & Very Practical \\
\hline Time & 75 & Practical \\
\hline Practical Value & 90,63 & Very Practical \\
\hline
\end{tabular}

Based on the teacher evaluation chart, it can be seen that the learning tools developed fall into very practical categories.

The effectiveness of the pedagogical devices is based on the competence of the learners acquired during the learning process. This is seen from the classical completeness acquired by learners of the three aspects of knowledge, attitude and skills. On the basis of the field tests that have been carried out show that the learning tool based on comparative intelligence on trigonometric material developed met the effective criteria. This can be seen from Koginitf's mathematical test which shows that over $73 \%$ of learners have reached KKM. Affective learning outcomes achieved an average percentage of $84 \%$. The psychomotor learning scores obtained an average percentage of $81 \%$. Thus, a mathematical learning tool based on the theory of multiple intelligences can be considered effective.

\section{CONCLUSION}

The trigonometric devices based on the theory of multiple intelligences developed in this study meet the criteria of validity, practicality and efficiency. The plomp model used in this research comprises three steps: the preliminary research, the prototyping phase and the evaluation phase are very useful for developing trigonometric learning tools based on the theory of multiple intelligences. By enhancing the learners' intelligence, learners become more active in the learning process and can relate the subject to daily life or other sciences. In addition, learners can explore and learn in their own way through the strongest / most dominant intelligence they have. More importantly, not only the knowledge and mathematical skills possessed by the learners, but also a good attitude.

\section{REFERENCES}

[1] Gardner. H, Frames of minds the theory of multiple intelligences, New York: Basic Books, 2011

[2] Fleetham. M, Multiple intelligences in practice: enhacing self-esteem and learning in the classroom, Stafford: Network Continuum Education, 2006.

[3] Widjajanti. D.B, "Teori kecerdasan majemuk: apa dan bagaimana mengaplikasikannya dalam pembelajaran matematika", Prosiding Seminar Nasional Penelitian, Pendidikan dan Penerapan MIPA,FMIPA, Universitas Negeri Yogyakarta, pp. 1-7, 2012.

[4] Kemendikbud, Peraturan Menteri Pendidikan dan Kebudayaan Nomor 21 Tahun 2016 tentang Standar Isi Pendidikan Dasar dan Menengah, 2016.

[5] Ula. S.S, Revolusi belajar: optimalisasi kecerdasan melalui pembelajaran berbasis kecerdasan majemuk, Yogyakarta: Ar-ruzz Media, 2013.

[6] McElmeel. S.L, Character education: a book guide for teachers, librarians, and parents, Colorado: Greenwood Publishing Group, Inc, 2002

[7] Burton. K, \& Platts. B, Building confidence for dummies. Chichester: John Wliey \& Sons, Ltd, 2006.
[8] Stevenson. N, Young person's character education handbook, Otis Avenue, Indianapolis: JIST Publishing, Inc, 2006.

[9] Lauster. P, Tes kepribadian, Jakarta: Bumi Aksara, 2005

[10] Kroll. W, Critical attitude: what keeps me from growing, Lincoln: The Good News Broadcasting Association, Inc, 2012.

[11] Zuss. M, The practice of theoretical curiosity, New York: Springer, 2012.

[12] Armstrong. T, Multiple intelligences in the classroom. (3rd ed), (Terjemahan Dyah Widya Prabaningrum), Alexandria, VA: Association for Supervision and Curriculum Development (ASCD), 2013.

[13] Bas. G, \& Beyhan. O, "Effects of multiple intelligences supported project-based learning on students' achievement levels and attitudes towards English lesson", International Electronic Journal of Elementary Education. Vol. 2, Issue 3, 2010. Accessed 30 November 2014, dari www.iejee.com/2_3_2010/365-385.pdf/

[14] Cicek. V, \& Tok. H, "Effective use of lesson plan to enhance education in U.S and Turkish kindergarten thru 12th grade public school system: a comparative study", International Journal of Teaching and Education, Vol. II, No. 2, pp. 10-20, 2013.

[15] Xie. J, \&Lin. R, "Research on multiple intelligences teaching and assessment", Asian Journal of Management and Humanity Sciences, Vol. 4, No. 2-3, pp. 106-124, 2009.

[16] Yalmanci. S.G, \& Gozum. C.A.I.C, "The effects of multiple intelligence theory based teaching on students' achievement and retention of knowledge (example of the enzymes subject)", International Journal on New Trends in Education and Their Implication, Vol. 4, Issue. 3, pp. 27-36, 2013.

[17] Wicaksono, D.P., Kusmayadi, T.A., \& Usodo. B, "Pengembangan perangkat pembelajaran matematika berbahasa inggis berdasakan teori kecerdasan majemuk (multiple intelligences) pada materi balok dan kubus untuk kelas VIII SMP", Jurnal elektronik pembelajaran matematika, Vol. 2 No. 5, 534-549, 2014.

[18] Yuliyanto \& Jailani, "Pengembangan Perangkat Pembelajaran Geometri SMP Menggunakan Metode Penemuan Terbimbing Pada Kelas VIII Semester II", Jurnal Riset Pendidikan Matematika, 1.1, pp. 127-138, 2014.

[19] Margaretha Madha Melissa, "Pengembangan Perangkat Pembelajaran Lingkaran Berbasis Teori Kecerdasan Majemuk Gardner Dan Berorientasi Pada Prestasi Belajar Matematika", Prosiding ISBN : 978-979-17763-9-4, 2015.

[20] Nieveen. N, Prototyping to reach product quality, Dalam Akker, J.V. et al. Design approaches and tools ineducation and training .London: Springer-Science+Business Media, B.V, 1999.

[21] Trianto, Mendesain model pembelajaran inovatif-progresif: konsep, landasan, dan implementasinya pada Kurikulum Tingkat Satuan Pendidikan (KTSP)", Jakarta: Kencana, 2011.

[22] Borg. W.R \& Gall. M.D, Educational research an introduction.(4th ed). New York: Longman Inc, 1983.

[23] Akker. J. V \& Plomp. Tjeerd, Educational Development in Developing Countries. Dalam Skutsch, Margaret M, Opda, J. Hans M. And Nordholt, Nico G Schulte (Eds.), TowardsSustainable Development. Enschede: Tecnology and Development Group University of Twente, 1994.

[24] Tessmer. Martin, Planning And Conducting Formative Evaluation, Philadelphia :Kogan Page, 1998

[25] McKenzie. W, Multiple intelligences and instructional technology. (2nd ed.), Washington, DC: International Society for Technology in Education (ISTE), 2005. 